\title{
PENGARUH PELATIHAN KOMUNIKASI INTERPERSONAL TERHADAP KEPUASAN RELASI DENGAN REKAN KERJA PADA GURU
}

\author{
Yudie Damar Muruf \\ Magister Psikologi Profesi Universitas Mercu Buana Yogyakarta \\ email: Yudhi@gmail.com
}

\begin{abstract}
Abstrak
Penelitian ini menguji pengaruh pelatihan komunikasi interpersonal terhadap kepuasan relasi dengan rekan kerja pada guru. Penelitian eksperimen-kuasi ini melibatkan 30 orang guru (15 orang kelompok kontrol dan 15 orang kelompok eksperimen). Skala Kepuasan Relasi digunakan untuk mengumpulkan data. Hasil analisis statistik uji-t terhadap gain score kelompok eksperimen dan kelompok kontrol dengan menggunakan independent sample t-test, menunjukkan nilai thitung $6,961>\mathrm{t}_{\text {tabel }} 2,048(\mathrm{p}<0,05)$. Hal ini menunjukkan bahwa terdapat perbedaan tingkat kepuasan relasi di antara kelompok eksperimen dan kelompok kontrol setelah pemberian perlakuan. Hasil mean gain score kelompok eksperimen juga lebih besar dibandingkan dengan kelompok kontrol $(8,47>0,20)$, sehingga dapat disimpulkan bahwa kelompok eksperimen yang mendapat pelatihan komunikasi interpersonal menunjukkan peningkatan kepuasan relasi dibandingkan kelompok kontrol yang tidak mendapatkan pelatihan.
\end{abstract}

Kata Kunci : Kepuasan Relasi, Pelatihan Komunikasi Interpersonal

\section{EFFECT OF INTERPERSONAL COMMUNICATION TRAINING ON RELATION SATISFACTION WITH THE WORKING TEACHER ON \\ TEACHER}

\author{
Yudie Damar Muruf \\ Magister Psikologi Profesi Universitas Mercu Buana Yogyakarta \\ email: Yudhi@gmail.com
}

\begin{abstract}
This study examines the effect of interpersonal communication training on the satisfaction of relationships with colleagues in teachers. The quasi-experimental study involved 30 teachers (15 controls and 15 experimental groups). Relationship Satisfaction Scale is used to collect data. The result of t-test statistic analysis on gain score of experimental group and control group using independent sample t-test shows thitung value of $6,961>$ ttable $2.048(\mathrm{p}<0,05)$. This shows that there is a difference in the level of relationship satisfaction between the experimental group and the control group after treatment. The result of experimental group gain mean score is bigger than control group $(8,47>0,20)$, so it can be concluded that


experimental group that received interpersonal communication training showed increased relation satisfaction compared to control group that did not get training.

Keywords: Relationship Satisfaction, Interpersonal Communication Training

\section{PENDAHULUAN}

Dewasa ini perkembangan di dunia institusi pendidikan khususnya sekolah bertumbuh dengan sangat pesat. Hal ini tentu saja berkaitan dengan peran sumber daya yang dimiliki oleh sekolah tersebut, antara lain sumber daya manusia yaitu guru. Robbins (1996) mengatakan SDM atau sumber daya manusia merupakan komponen penting dalam suatu organisasi karena kualitas yang baik dari SDM telah terbukti mempunyai dampak yang besar terhadap kinerja organisasi. Peran guru selain bertugas untuk mengajar para muridnya tetapi juga membangun suasana yang kondusif dan produktif bagi organisasinya, yaitu sekolah.

Salah satu hal yang dapat membantu guru dalam menjalankan tanggung jawab dan mengurangi beban moral, sehingga kinerja guru dalam bekerja tetap maksimal adalah dengan menjaga tingkat kepuasan relasi, terutama di dengan rekan sekerja dalam organisasi atau instansi tempat guru tersebut mengajar. Dukungan sosial yang berasal dari relasi dengan rekan sekerja mampu membantu guru mendapatkan saran, umpan balik dan kekuatan secara emosional untuk mengurangi timbulnya stres kerja, perasaan tertekan dan ketidakpuasan dari pekerjaan guru tersebut
(Murtiningrum, 2005). Penelitian yang dilakukan oleh Hawthorne (Roethlisberger \& Dickson, 1939) menunjukkan bahwa relasi yang terjalin di antara rekan kerja merupakan salah satu faktor penting yang mempengaruhi sikap dan kinerja seorang pekerja. Melalui kepuasan relasi yang terjalin, organisasi dapat meningkatkan potensi pekerjanya secara efektif.

Salah satu faktor yang berperan dalam mempengaruhi kepuasan relasi, terutama dengan rekan sekerja adalah komunikasi interpersonal yang terjalin di dalam organisasi atau instansi tempat guru tersebut mengajar. Muhammad (2005) mengatakan bahwa selain hal-hal yang bersifat materiil, keinginan manusia yang paling besar adalah membentuk dan memelihara relasi dengan orang lain. Manusia selalu berusaha untuk berhubungan dengan manusia lain guna memaksimalkan kesenangan yang bisa didapatkan dan meminimalkan penderitaan yang mungkin diterima. Manusia perlu berbagi rasa dengan orang lain mengenai nasib, penderitaan emosi atau fisik sesuai dengan hakikat manusia sebagai makhluk sosial (Qolbi, 2013). Pada saat inilah peran komunikasi interpersonal terlihat, karena salah satu tujuan penting dari komunikasi interpersonal adalah membentuk 
dan menjaga relasi yang penuh arti serta memuaskan di antara kedua belah pihak yang terlibat. Hal ini berarti, semakin memuaskan komunikasi interpersonal yang terjadi, maka hubungan atau relasi yang terjalin akan semakin berarti dan semakin memuaskan. Saat individu merasa dimengerti dan dihargai oleh rekannya melalui komunikasi yang memuaskan, maka individu tersebut akan mulai membuka diri untuk menjalin relasi, bertahan dalam relasi tersebut dan akhirnya mengalami pengalaman relasi yang memuaskan (Anderson \& Martin, 2009).

Selain perihal di atas, sistem di sekolahsekolah juga mengharuskan guru untuk sering berkomunikasi dengan atasannya (kepala sekolah atau supervisor), kolega, para murid dan orang tua murid (Rosenholtz, 1989), sehingga guru dituntut untuk memiliki kemampuan komunikasi interpersonal yang baik. Interaksi yang terjadi memungkinkan guru yang bersangkutan untuk mendapatkan pencerahan dan pengetahuan tentang latar belakang, pengalaman, sikap dan perilaku masing-masing dari lingkungan sekerjanya. Magnus (Orebiyi \& Orebiyi, 2011) berpendapat bahwa komunikasi interpersonal yang efektif sangat penting bagi interaksi sosial untuk membangun serta memelihara kepuasan relasi yang ada di lingkungan sekolah. Individu dengan kemampuan komunikasi interpersonal yang kuat dapat mengatasi stres lebih baik, memiliki kepuasan relasi yang lebih baik dan memiliki banyak teman, mampu beradaptasi dengan perubahan hidup serta cenderung terhindar dari depresi dan kecemasan (Segrin \& Flora, 2000).
Magnus (2009) memperingatkan bahwa komunikasi interpersonal yang buruk dapat menyebabkan buruknya relasi di lingkungan kerja yang berefek pada menurunnya produktivitas, kepercayaan, saling menghormati dan komitmen kerja. Hecht (Anderson \& Emmers-Sommer, 2006) juga menambahkan bahwa komunikasi interpersonal yang memuaskan dapat membantu individu untuk membangun hubungan yang memuaskan pula. Berdasarkan penjelasan dan penelitian di atas dapat disimpulkan bahwa komunikasi interpersonal mempengaruhi kepuasan relasi yang dirasakan oleh guru. Hal ini berarti semakin baik komunikasi interpersonal yang dimiliki dan diciptakan oleh guru, maka akan semakin baik pula tingkat kepuasan relasi yang dirasakan oleh guru tersebut, terutama kepuasan relasi dengan rekan sekerja.

Berangkat dari hubungan ini maka diperlukan suatu metode intervensi untuk meningkatkan kemampuan komunikasi interpersonal guru, yang nantinya akan berdampak pula kepada peningkatan kepuasan relasi dengan rekan kerja seiring dengan meningkatnya kemampuan komunikasi interpersonal guru yang bersangkutan. Salah satu metode intervensi untuk dapat meningkatkan kemampuan komunikasi interpersonal dari para guru adalah metode pelatihan. Metode pelatihan dipilih karena menurut peneliti komunikasi interpersonal merupakan suatu kemampuan atau keterampilan dalam hal berkomunikasi secara mendalam yang dapat dipelajari dan dilatih melalui pelatihan. Hal ini sejalan dengan 
tujuan dilaksanakannya pelatihan menurut Panggabean (2002), yaitu untuk memberikan atau meningkatkan keterampilan yang dibutuhkan oleh seorang pekerja untuk melaksanakan pekerjaannya sekarang. Selain itu menurut Negri dan kawan-kawan (1993) pemberian metode intervensi pelatihan, khususnya pelatihan komunikasi interpersonal terbukti memberikan dampak yang nyata bagi peningkatan kesadaran dan kemampuan komunikasi interpersonal para praktikannya, serta berkaitan pula dengan kepuasan relasi dan pelayanan. Hasil penelitian Susilowati (2012) juga menguatkan dengan menunjukkan bahwa skor rata-rata kompetensi komunikasi interpersonal sesudah pelatihan komunikasi interpersonal diberikan, lebih tinggi dibandingkan sebelum pelatihan. Maka dapat disimpulkan bahwa pelatihan komunikasi interpersonal efektif dalam meningkatkan kompetensi komunikasi interpersonal.

Pelatihan yang dirancang oleh peneliti merupakan pelatihan komunikasi interpersonal, karena materi-materi yang disampaikan disusun berdasarkan aspek-aspek komunikasi interpersonal milik DeVito (2006) yaitu keterbukaan, empati, dukungan, sikap positif dan kesetaraan. Peneliti menggunakan aspek-aspek komunikasi interpersonal milik DeVito (2006) karena pendapatnya cukup komprehensif dan sering digunakan dalam banyak penelitian untuk menjelaskan aspekaspek komunikasi interpersonal. Modul pelatihan ini juga diadaptasi dari modul Interpersonal Communication in Information, Education and Counseling milik Training Model Primary Providers (2006) dan diselenggarakan berdasarkan metode serta prinsip “experience learning”. Secara umum modul ini bertujuan untuk meningkatkan kemampuan komunikasi interpersonal dari para pesertanya, yang berprofesi sebagai guru. Secara khusus materi-materi yang akan dijelaskan dalam sesi pelatihan yang telah dirancang oleh peneliti ke dalam 3 (tiga) sesi besar antara lain akan menjelaskan tentang pengertian komunikasi interpersonal; komponen-komponen penyusun komunikasi interpersonal dan proses komunikasi interpersonal; manfaat dan tujuan komunikasi interpersonal; aspek-aspek komunikasi interpersonal seperti keterbukaan, empati, dukungan, sikap positif dan kesetaraan; serta terakhir faktor-faktor efektifitas komunikasi interpersonal.

Berdasarkan uraian di atas, maka hubungan pengaruh yang dapat diasumsikan oleh peneliti adalah kepuasan relasi dipengaruhi oleh komunikasi interpersonal, sehingga diperlukan kemampuan komunikasi interpersonal yang baik. Kemampuan komunikasi interpersonal inilah yang kemudian akan ditingkatkan melalui pelatihan komunikasi interpersonal, sehingga setelah peserta memiliki kemampuan komunikasi interpersonal yang baik, diasumsikan hal ini akan berpengaruh positif terhadap kepuasan relasi, khususnya dengan rekan sekerja. Perumusan masalah dalam penelitian ini adalah untuk mengetahui apakah terdapat pengaruh pelatihan komunikasi interpersonal terhadap peningkatan kepuasan relasi, khususnya dengan rekan sekerja pada guru. 


\section{KAJIAN TEORI}

\section{Kepuasan Relasi}

Smith (Simon, Judge \& HalvorsenGanepola, 2010) mendefinisikan kepuasan relasi khususnya dengan rekan kerja, adalah sebuah respon afektif dan evaluasi kognisi secara positif kepada rekan sekerja individu yang bersangkutan. Indikator kepuasan relasi sendiri menurut Anderson dan EmmersSommer (2006) adalah merasa terdapat kesamaan (similarity), adanya komitmen (commitment), intimasi (intimacy), rasa kepercayaan (trust), kepuasan komunikasi (communication satisfaction) serta kemampuan untuk mengerti dan memperkirakan perilaku orang lain (attributional confidence). Teori Pertukaran Sosial (Social Exchange Theory) adalah suatu pendekatan yang seringkali digunakan untuk menjelaskan tentang kepuasan relasi. Asumsi dasar Teori Pertukaran Sosial adalah setiap individu akan secara sukarela memasuki dan tinggal dalam suatu hubungan sosial hanya selama hubungan tersebut cukup memuaskan ditinjau dari segi ganjaran, biaya, laba dan tingkat perbandingan. Teori ini memandang hubungan sebagai suatu transaksi dagang. Orang berhubungan dengan orang lain karena mengharapkan sesuatu untuk memenuhi kebutuhannya (West \& Turner, 2009).

\section{Pelatihan Komunikasi Interpersonal}

Pelatihan komunikasi interpersonal merupakan metode yang dipilih dan dirancang oleh peneliti guna meningkatkan komunikasi interpersonal, karena materi-materi yang disampaikan disusun berdasarkan aspek-aspek komunikasi interpersonal milik DeVito (2006) yaitu keterbukaan, empati, dukungan, sikap positif dan kesetaraan. Peneliti menggunakan aspek-aspek komunikasi interpersonal milik DeVito (2006) karena pendapatnya cukup komprehensif dan sering digunakan dalam banyak penelitian untuk menjelaskan aspekaspek komunikasi interpersonal. Modul dalam pelatihan ini juga diadaptasi dari modul Interpersonal Communication in Information, Education and Counseling milik Training Model Primary Providers (2006) dan diselenggarakan berdasarkan metode serta prinsip "experience learning”. Metode pelatihan dipilih karena menurut Negri dan kawan-kawan (1993), salah satu metode intervensi yang efektif untuk dapat meningkatkan kemampuan komunikasi interpersonal adalah metode pelatihan khususnya pelatihan komunikasi interpersonal. Hasil penelitian Susilowati (2012) juga menguatkan dengan menunjukkan bahwa skor rata-rata kompetensi komunikasi interpersonal sesudah pelatihan komunikasi interpersonal diberikan, lebih tinggi dibandingkan sebelum pelatihan.

Secara umum modul ini bertujuan untuk meningkatkan kemampuan komunikasi interpersonal dari para pesertanya, yang berprofesi sebagai guru. Secara khusus materimateri yang akan dijelaskan dalam sesi pelatihan yang telah dirancang oleh peneliti ke dalam 3 (tiga) sesi besar, antara lain akan menjelaskan tentang pengertian komunikasi interpersonal; komponen-komponen penyusun komunikasi interpersonal dan proses komunikasi interpersonal; manfaat dan tujuan 
komunikasi interpersonal; aspek-aspek komunikasi interpersonal seperti keterbukaan, empati, dukungan, sikap positif dan kesetaraan; serta terakhir faktor-faktor efektifitas komunikasi interpersonal.

\section{METODE PENELITIAN}

Jenis penelitian yang digunakan dalam penelitian ini adalah eksperimental kuasi dengan desain penelitiannya yaitu The Untreated Control Group Design With Dependent Pretest and Posttest Samples (Shadish, Cook \& Campbell, 2002). Subjek dalam penelitian ini adalah guru sekolah dasar (SD) yang ada di Salatiga. Subjek penelitian akan dibagi dalam 2 kelompok, yaitu kelompok eksperimen dan kelompok kontrol. Kelompok eksperimen adalah kelompok yang mendapatkan perlakuan berupa pemberian pelatihan komunikasi interpersonal dan sekaligus diberikan pretest maupun posttest, sedangkan kelompok kontrol adalah adalah kelompok yang tidak mendapatkan perlakuan (tidak mengikuti pelatihan komunikasi interpersonla) tetapi diberikan pretest dan posttest. Karakteristik subjek dalam penelitian ini adalah sebagai berikut :

\section{Berprofesi sebagai guru/pengajar}

2. Sehat baik secara fisik maupun mental

3. Telah bekerja lebih dari 1 tahun

4. Memiliki rekan kerja (tidak bekerja sendirian/terpisah)

5. Berdasarkan hasil pretest memiliki nilai kepuasan relasi yang masuk dalam kategori sedang, rendah atau rendah sekali

InSight, Tahun XIII/Nomor 1/Februari 2016
Pengambilan data dalam penelitian ini dilakukan dengan menggunakan skala kepuasan relasi. Skala kepuasan relasi yang digunakan dalam penelitian ini disusun berdasarkan indikator-indikator kepuasan relasi milik Anderson dan Emmers-Sommer (2006), yaitu merasa terdapat kesamaan (similarity), adanya komitmen (commitment), intimasi (intimacy), rasa kepercayaan (trust), kepuasan komunikasi (communication satisfaction) serta kemampuan untuk mengerti dan memperkirakan perilaku orang lain (attributional confidence). Selain itu, bentuk skala yang digunakan dalam penelitian ini adalah skala likert. Menurut Sugiyono (2010), skala likert adalah skala yang digunakan untuk mengukur sikap, pendapat dan persepsi seseorang atau sekelompok orang tentang fenomena sosial. Skala kepuasan relasi pada penelitian ini terdiri dari 42 item yang terbagi menjadi 21 item favorable dan 21 item unfavorable. Skala ini kemudian diujicobakan kepada 80 orang guru, tetapi hanya 60 skala yang kembali kepada peneliti untuk dilakukan uji validitas dan reliabilitas alat ukur. Berdasarkan hasil perhitungan uji validitas dan reliabilitas didapatkan 17 item yang valid dengan nilai reliabilitas sebesar 0.895 (reliabel). Prosedur pengambilan dan pengumpulan data terbagi menjadi dua tahap, yaitu tahap persiapan penelitian dengan urutan prosedur penyusunan instrumen, uji coba skala, penyusunan modul pelatihan, uji coba modul, persiapan pelatih, alasan pemilihan subjek penelitian, perijinan penelitian, dan terakhir pembagian kelompok eksperimen dan kelompok kontrol. Tahap selanjutnya adalah 
tahap pelaksanaan penelitian dengan urutan prosedur pemberian pretest, kontrol terhadap validitas internal, pelaksanaan pelatihan, follow up setelah pelatihan dan terakhir pemberian posttest. Langkah terakhir dalam penelitian ini adalah melakukan analisis data dengan menggunakan independent sample ttest

\section{HASIL DAN PEMBAHASAN}

Berdasarkan hasil analisis statistik uji-t terhadap data posttest $\mathrm{KK}$ dan KE, dengan $\alpha=$ $5 \%$, maka diketahui bahwa nilai signifikansi posttest variabel kepuasan relasi (VT) adalah sebesar $0,000<0,05\left(\mathrm{H}_{0}\right.$ ditolak dan $\mathrm{H}_{1}$ diterima) dengan mean $\mathrm{KK}<$ mean $\mathrm{KE}(52,60$ $<60,53)$. Selain itu hasil analisis statistik uji-t terhadap gain score kelompok eksperimen dan kelompok kontrol dengan menggunakan independent sample t-test, menunjukkan nilai $\mathrm{t}_{\text {hitung }} 6,961>\mathrm{t}_{\text {tabel }} 2,048(\mathrm{p}<0,05)$ dengan mean gain score $\mathrm{KK}<$ mean gain score $\mathrm{KE}$ $(0,20>8,47)$, sehingga dapat disimpulkan bahwa pemberian pelatihan komunikasi interpersonal berpengaruh dalam meningkatkan kepuasan relasi dari guru di SD "A" yang menjadi kelompok eksperimen. Selain itu berdasarkan penelitian tentang pengaruh pelatihan komunikasi interpersonal terhadap kepuasan relasi dengan rekan kerja pada guru melalui pretest dan posttest, didapatkan hasil bahwa secara umum kepuasan relasi pada SD "B" sebagai kelompok kontrol (KK) berada pada kategori sedang (pretest $=13$ orang $/ 86,7 \%$ subjek dengan mean 52,40 dan SD sebesar 4,256 posttest $=15$ orang $/ 100 \%$ subjek dengan mean
52,60 dan SD sebesar 3,924). Baik hasil pretest maupun posttest dari kelompok kontrol (KK) menunjukkan bahwa subjek pada kelompok ini memiliki kepuasan relasi yang stabil pada kategori sedang tanpa adanya pemberian perlakuan berupa pelatihan komunikasi interpersonal. Sebaliknya kepuasan relasi pada pada SD "A" sebagai kelompok eksperimen (KE) yang dihitung melalui pretest dan posttest, didapatkan hasil bahwa secara umum kepuasan relasi pada kelompok eksperimen sebelum diberikan pelatihan berada pada kategori sedang (pretest $=13$ orang $/ 86,7 \%$ subjek dengan mean sebesar 52,07 dan SD sebesar 4,131). Kemudian setelah diberikan perlakuan (VB) berupa pelatihan komunikasi interpersonal kepada subjek kelompok eksperimen dan dilakukan pengukuran melalui posttest, diketahui bahwa terjadi peningkatan kepuasan relasi dari kategori sedang menuju ke kategori tinggi (posttest $=9$ orang $/ 60 \%$ subjek dengan mean sebesar 60,53 dan standar deviasi sebesar 6,728).

Comer (1991) mengatakan bahwa sebagian besar waktu yang dilalui oleh seorang pekerja lebih banyak dihabiskan untuk menjalin relasi dengan rekan kerjanya dibanding pihak lain di tempatnya bekerja, bahkan dengan keluarganya sendiri. Relasi dengan rekan kerja mengacu pada hubungan yang terjadi di antara rekan kerja dalam satu tingkat jabatan, dengan bawahan maupun dengan atasannya, walaupun pada umumnya relasi dengan rekan kerja lebih sering diartikan sebagai hubungan yang terjalin di antara karyawan dengan level jabatan yang sama dan InSight, Tahun XIII/Nomor 1/Februari 2016 
tidak memiliki otoritas satu sama lain (Rubin \& Rubin, 1995). Kepuasan terhadap relasi yang dijalani oleh guru tersebut sangat penting dalam menjalankan tugas dan perannya. Peran guru selain mengajar para muridnya juga membangun suasana yang kondusif dan produktif bagi organisasinya.

Salah satu hal yang mempengaruhi kepuasan relasi, terutama dengan rekan sekerja adalah komunikasi interpersonal yang terjalin di dalam organisasi atau instansi tempat guru tersebut mengajar. Muhammad (2005) mengatakan bahwa selain hal-hal yang bersifat materiil, keinginan manusia yang paling besar adalah membentuk dan memelihara relasi dengan orang lain. Manusia selalu berusaha untuk berhubungan dengan manusia lain guna memaksimalkan kesenangan yang bisa didapatkan dan meminimalkan penderitaan yang mungkin diterima. Hal ini sesuai dengan konsep Teori Pertukaran Sosial yang mengatakan bahwa individu akan bertahan dalam sebuah hubungan selama individu tersebut menerima lebih banyak ganjaran/reward dibandingkan pengorbanan/cost. Manusia perlu berbagi rasa dengan orang lain mengenai nasib, penderitaan emosi atau fisik sesuai dengan hakikat manusia sebagai makhluk sosial (Qolbi, 2013). Pada saat inilah peran komunikasi interpersonal terlihat, karena salah satu tujuan penting dari komunikasi interpersonal adalah membentuk dan menjaga relasi yang penuh arti serta memuaskan di antara kedua belah pihak yang terlibat. Hal ini berarti, semakin memuaskan komunikasi interpersonal yang terjadi, maka hubungan atau relasi yang

InSight, Tahun XIII/Nomor 1/Februari 2016 terjalin akan semakin berarti dan semakin memuaskan. Hecht (Anderson \& EmmersSommer, 2006) kemudian juga menambahkan dengan mengatakan bahwa komunikasi interpersonal yang memuaskan dapat membantu individu untuk membangun hubungan yang memuaskan pula. Saat individu merasa dimengerti dan dihargai oleh rekannya melalui komunikasi yang memuaskan, maka individu tersebut akan mulai membuka diri untuk menjalin relasi, bertahan dalam relasi tersebut dan akhirnya mengalami pengalaman relasi yang memuaskan (Anderson \& Martin, 2009).

Selain perihal di atas, sistem di sekolahsekolah juga mengharuskan guru untuk sering berkomunikasi dengan atasannya (kepala sekolah atau supervisor), kolega, para murid dan orang tua murid (Rosenholtz, 1989), sehingga guru dituntut untuk memiliki kemampuan komunikasi interpersonal yang baik. Magnus (Orebiyi \& Orebiyi, 2011) berpendapat bahwa komunikasi interpersonal yang efektif sangat penting bagi interaksi sosial untuk membangun serta memelihara kepuasan relasi yang ada di lingkungan sekolah. Individu dengan kemampuan komunikasi interpersonal yang kuat dapat mengatasi stres lebih baik, memiliki kepuasan relasi yang lebih baik dan memiliki banyak teman, mampu beradaptasi dengan perubahan hidup serta cenderung terhindar dari depresi dan kecemasan (Segrin \& Flora, 2000). Magnus (2009) memperingatkan bahwa komunikasi interpersonal yang buruk dapat menyebabkan buruknya relasi di lingkungan kerja yang berefek pada menurunnya 
produktivitas, kepercayaan, saling menghormati dan komitmen kerja. Hecht (Anderson \& Emmers-Sommer, 2006) juga menambahkan bahwa komunikasi interpersonal yang memuaskan dapat membantu individu untuk membangun hubungan yang memuaskan pula. Penelitian yang dilakukan Emmers-Sommer (Anderson \& Emmers-Sommer, 2006) juga menemukan bahwa terdapat hubungan langsung antara kualitas komunikasi antar rekan sekerja dengan kepuasan relasi. Berdasarkan penjelasan dan penelitian di atas dapat disimpulkan bahwa komunikasi interpersonal mempengaruhi kepuasan relasi yang dirasakan oleh guru. Hal ini berarti semakin baik komunikasi interpersonal yang dimiliki dan diciptakan oleh guru, maka akan semakin baik pula tingkat kepuasan relasi yang dirasakan oleh guru tersebut, terutama kepuasan relasi dengan rekan sekerja. Berangkat dari hubungan ini maka diperlukan suatu metode intervensi untuk meningkatkan kemampuan komunikasi interpersonal guru, yang nantinya akan berdampak pula kepada peningkatan kepuasan relasi dengan rekan kerja seiring dengan meningkatnya kemampuan komunikasi interpersonal guru yang bersangkutan. Salah satu metode intervensi untuk dapat meningkatkan kemampuan komunikasi interpersonal dari para guru adalah metode pelatihan. Metode pelatihan dipilih karena menurut peneliti komunikasi interpersonal merupakan suatu kemampuan atau keterampilan dalam hal berkomunikasi secara mendalam yang dapat dipelajari dan dilatih melalui pelatihan. Hal ini sejalan dengan tujuan dilaksanakannya pelatihan menurut Panggabean (2002), yaitu untuk memberikan atau meningkatkan keterampilan yang dibutuhkan oleh seorang pekerja untuk melaksanakan pekerjaannya sekarang. Selain itu menurut Negri dan kawan-kawan (1993) pemberian metode intervensi pelatihan, khususnya pelatihan komunikasi interpersonal terbukti memberikan dampak yang nyata bagi peningkatan kesadaran dan kemampuan komunikasi interpersonal para praktikannya, serta berkaitan pula dengan kepuasan relasi dan pelayanan. Hasil penelitian Susilowati (2012) juga menguatkan dengan menunjukkan bahwa skor rata-rata kompetensi komunikasi interpersonal sesudah pelatihan komunikasi interpersonal diberikan, lebih tinggi dibandingkan sebelum pelatihan. Maka dapat disimpulkan bahwa pelatihan komunikasi interpersonal efektif dalam meningkatkan kompetensi komunikasi interpersonal.

Pelatihan yang dirancang oleh peneliti merupakan pelatihan komunikasi interpersonal, karena materi-materi yang disampaikan disusun berdasarkan aspek-aspek komunikasi interpersonal milik DeVito (2006) yaitu keterbukaan, empati, dukungan, sikap positif dan kesetaraan. Peneliti menggunakan aspek-aspek komunikasi interpersonal milik DeVito (2006) karena pendapatnya cukup komprehensif dan sering digunakan dalam banyak penelitian untuk menjelaskan aspekaspek komunikasi interpersonal. Modul pelatihan ini juga diadaptasi dari modul Interpersonal Communication in Information, Education and Counseling milik Training Model Primary Providers (2006) dan InSight, Tahun XIII/Nomor 1/Februari 2016 
diselenggarakan berdasarkan metode serta prinsip “experience learning”. Secara umum modul ini bertujuan untuk meningkatkan kemampuan komunikasi interpersonal dari para pesertanya, yang berprofesi sebagai guru dan materi-materi dalam pelatihan ini dibagi menjadi 3 (tiga) sesi besar.

Sesi pertama merupakan sesi pengantar yang menjelaskan tentang pengertian komunikasi interpersonal, komponenkomponen penyusun komunikasi interpersonal dan proses komunikasi interpersonal serta manfaat dan tujuan komunikasi interpersonal. Target umum dari sesi ini adalah peserta diharapkan dapat mengetahui dan mendeskripsikan informasi umum mengenai komunikasi interpersonal sebagai pondasi dasar dalam memahami materi-materi komunikasi interpersonal secara lebih mendalam lagi pada sesi berikutnya. Notoatmodjo (1993) berpendapat bahwa semakin banyak informasi dapat mempengaruhi atau menambah pengetahuan seseorang, maka akan menimbulkan kesadaran yang pada akhirnya membuat seseorang berperilaku sesuai dengan pengetahuan yang dimilikinya. Sesi kedua berkaitan dengan aspek-aspek komunikasi interpersonal milik DeVito (2006). Menurut penelitian kualitatif yang dilakukan oleh Kusumaningrum (2014) diketahui bahwa kepuasan relasi dapat dicapai dengan menggunakan pendekatan lima dimensi komunikasi interpersonal milik DeVito. Pada sesi ini Trainer akan menjelaskan dan melatih peserta untuk dapat mengetahui bahkan mempraktekkan aspekaspek komunikasi interpersonal seperti keterbukaan, empati, dukungan, sikap positif dan kesetaraan dengan baik. Aspek-aspek komunikasi interpersonal inilah yang diharapkan dapat bersinergi dan mempengaruhi aspek-aspek kepuasan relasi.

Aspek pertama adalah keterbukaan, didefinisikan sebagai kemampuan untuk mengungkapkan unsur-unsur kepribadian diri sendiri melalui komunikasi (Rubin \& Martin, 1994). Menurut Devito (2006) kualitas keterbukaan mengacu pada sedikitnya tiga hal penting. Pertama, komunikator yang efektif harus terbuka kepada orang yang diajak untuk berinteraksi dan adanya kesediaan untuk membuka diri sepatutnya. Kedua, kesediaan komunikator untuk bereaksi secara jujur terhadap stimulus yang datang sehingga komunikator memperlihatkan keterbukaan dengan cara bereaksi secara spontan terhadap orang lain. Ketiga, menyangkut perasaan dan pikiran yaitu mengakui bahwa perasaan dan pikiran yang dilontarkan adalah memang yang sebenarnya dan diharapkan tanggung jawab atasnya. Saat seseorang berani terbuka tentang dirinya kepada orang lain dan keterbukaannya dibalas oleh orang tersebut, maka akan tercipta suasana nyaman dan saling percaya yang akan mempermudah terjalinnya komunikasi interpersonal. Hal ini sesuai dengan pendapat Rubent (1998) yang mengatakan bahwa sikap terbuka sangat besar pengaruhnya dalam menumbuhkan komunikasi interpersonal yang efektif. Magnus (Orebiyi \& Orebiyi, 2011) kemudian melengkapi dengan berpendapat bahwa komunikasi interpersonal yang efektif sangat penting bagi interaksi sosial untuk membangun serta memelihara kepuasan relasi. 
Berdasarkan hasil rangkuman sharing yang menjadi bagian dari evaluasi tugas monitoring pasca pelatihan pada penelitian ini, diketahui beberapa guru yang terlibat sebagai subjek memiliki keinginan untuk menceritakan beban yang dimilikinya kepada rekan kerjanya dan sudah mulai berani untuk belajar terbuka baik untuk menceritakan permasalahannya, ataupun memberikan saran kepada rekannya.

Secara umum keterbukaan dalam berkomunikasi dapat menimbulkan kepercayaan terhadap isi maupun pemberi pesan. Komunikator yang memiliki keterpaduan, kesesuaian antara ucapan dan tindakannya akan lebih disegani oleh komunikan. Selain itu integritas juga berkaitan dengan rasa saling dapat dipercaya di antara komunikator dan komunikan (Cutlip \& Allen, 2000). Semakin jujur dan terbuka proses komunikasi yang berlangsung, maka kedua belah pihak akan semakin puas terhadap komunikasi yang dijalani. Komunikasi yang memuaskan terjadi saat ekspektasi akan suatu interaksi dapat terpenuhi. Setelah itu saat individu merasa dimengerti dan dihargai oleh rekannya, maka individu tersebut akan mulai membuka diri untuk menjalin relasi, bertahan atau berkomitmen dalam relasi tersebut dan akhirnya mengalami pengalaman relasi yang memuaskan (Anderson \& Martin, 2009). Menurut para guru yang mengikuti proses evaluasi, keterbukaan menjadi penting dalam menjalin hubungan interpersonal karena keterbukaan yang berisi kejujuran akan membuat rasa aman dari kedua belah pihak yang saling berkomunikasi dan menjalin hubungan.
Aspek kedua adalah aspek empati (empathy). Empati didefinisikan sebagai kemampuan seseorang untuk merasakan apa yang sedang dirasakan orang lain pada suatu saat tertentu dari sudut pandang orang tersebut. Berempati adalah merasakan seperti orang yang mengalaminya. Orang yang berempati mampu memahami motivasi dan pengalaman orang lain, perasaan dan sikap mereka, serta harapan dan keinginan mereka untuk masa mendatang, sehingga membuat komunikator lebih mampu menyesuaikan komunikasinya (DeVito, 2006). Hal ini tentunya juga akan menciptakan hubungan yang intim di antara komunikator dan komunikan, karena konsep intimasi dalam kepuasan relasi berbicara tentang proses saling berbagi pikiran atau perhatian secara personal dan dapat juga dirasakan secara personal. Selain itu empati juga akan meningkatkan kemampuan untuk mengerti dan memperkirakan perilaku orang lain, yang merupakan salah satu aspek dari kepuasan relasi. Empati juga mempengaruhi konsep kepercayaan dalam kepuasan relasi, yaitu individu akan merasakan pengalaman subjektif yang dirasakan sebagai keyakinan, ketulusan dan rasa aman yang berangkat dari kebutuhan untuk dimengerti dan diperhatikan. Empati adalah salah satu faktor terbentuknya dukungan sosial (Hobfoll, 1986). Dukungan sosial yang berasal dari rasa empati seseorang terhadap rekan sekerjanya yang terfasilitasi melalui sebuah relasi yang berangkat dari komunikasi yang memuaskan, mampu memberikan kekuatan secara emosional untuk mengurangi timbulnya stres kerja, perasaan 
tertekan dan ketidakpuasan dari pekerjaan.

Semakin baik sebuah relasi terfasilitasi melalui komunikasi interpersonal yang tersampaikan dengan baik dan memuaskan, maka individu akan memilih untuk bertahan dalam relasi tersebut dan akhirnya mengalami pengalaman relasi yang memuaskan (Anderson \& Martin, 2009). Hal ini sesuai dengan konsep social exchange theory yang mengatakan bahwa setiap individu akan secara sukarela memasuki dan tinggal dalam suatu hubungan sosial hanya selama hubungan tersebut cukup memuaskan (West \& Turner, 2009).

Aspek ketiga adalah dukungan (supportif). Komunikasi yang terbuka dan empatik tidak dapat berlangsung dalam suasana yang tidak mendukung. Sikap suportif merupakan sikap yang dapat mengurangi sikap defensif. Sikap defensif muncul bila individu tidak dapat menerima, tidak jujur dan tidak empatik. Komunikasi defensif dapat terjadi karena faktor-faktor personal (ketakutan, kecemasan, harga diri yang rendah) atau faktor-faktor situasional yang berupa perilaku komunikasi orang lain. Sikap defensif mengakibatkan kualitas komunikasi interpersonal menjadi tidak efektif, karena orang yang defensif akan lebih banyak melindungi diri dari ancaman yang ditanggapinya dalam situasi memahami komunikasi. Hal ini tentu saja akan mempengaruhi kepuasan komunikasi yang berdampak pada ketidakpuasan relasi yang berlangsung, karena penelitian yang dilakukan Emmers-Sommer (Anderson \& EmmersSommer, 2006) mengatakan bahwa terdapat hubungan langsung antara kualitas komunikasi antar rekan sekerja dengan kepuasan relasi. Jadi dapat disimpulkan jika kualitas komunikasi tidak berjalan efektif, maka kepuasan relasinya juga akan terganggu. Aspek suportif juga berbicara mengenai bagaimana berkomunikasi secara deskriptif dan bukannya evaluatif terhadap lawan bicara. Hal ini berkaitan dengan salah satu aspek kepuasan relasi lainnya, yaitu mengerti dan memperkirakan perilaku orang lain. Deskriptif berarti individu mempersepsikan suatu komunikasi sebagai permintaan akan informasi, uraian mengenai suatu kejadian tertentu dan tidak bernada menilai atau evaluatif (Devito, 2006). Hal ini berarti komunikan berusaha mengerti dan memperkirakan perilaku lawan bicaranya tanpa keinginan untuk mengevaluasi, agar tercipta komunikasi interpersonal yang memuaskan. Selama tugas monitoring yang diberikan berjalan, banyak dari guru yang mulai mempraktekkan sikap tidak defensif dalam menerima saran dari rekannya, ada yang dengan konfrontasi ringan terlebih dahulu tetapi adapula yang langsung menerima dengan lapang dada.

Aspek keempat adalah sikap positif (positiveness). Sikap positif mengacu pada sedikitnya dua hal penting. Pertama, komunikasi akan dapat terbina dengan baik jika individu memiliki sikap positif terhadap diri mereka sendiri. Kedua, mempunyai perasaan positif terhadap orang lain dan berbagai situasi komunikasi. Suasana tidak menyenangkan akan muncul jika proses komunikasi berjalan dengan orang yang tidak menikmati interaksi atau bereaksi secara 
negatif terhadap suasana interaksi. Sikap positif dapat ditunjukkan dengan berbagai macam perilaku dan sikap, antara lain menghargai orang lain, berfikiran positif terhadap diri sendiri, berfikiran positif terhadap orang lain, tidak menaruh curiga secara berlebihan, meyakini pentingnya orang lain, memberikan pujian dan penghargaan serta memiliki komitmen untuk menjalin kerjasama. Hal ini bersinergi dengan aspek mengerti dan memperkirakan perilaku orang lain dalam kepuasan relasi, karena saat seseorang berfikiran positif terhadap orang lain, maka individu tersebut akan berusaha untuk merasionalisasikan, mengerti dan memperkirakan perilaku orang lainyang menjadi lawan bicaranya. Anderson dan Martin (2009) juga menambahkan saat individu merasa dimengerti dan dihargai oleh rekannya melalui komunikasi yang memuaskan, maka individu tersebut akan mulai membuka diri untuk menjalin relasi, bertahan dalam relasi tersebut dan akhirnya mengalami pengalaman relasi yang memuaskan.

Aspek kelima adalah kesetaraan (equality). Kesetaraan atau kesamaan ialah pengakuan bahwa kedua belah pihak memiliki kepentingan, kedua belah pihak sama-sama bernilai, berharga dan saling memerlukan. Rakhmat (2008) menjelaskan bahwa salah satu faktor yang mempengaruhi sebuah hubungan adalah faktor kesamaan atau kesetaraan. Orang-orang yang memiliki kesamaan dalam nilai-nilai, sikap, keyakinan, tingkat sosioekonomis, agama, ideologis, cenderung saling menyukai. Saat kedua belah pihak sudah saling menyukai, maka kecenderungan yang terjadi adalah terjalinnya komunikasi interpersonal yang memuaskan. Berdasarkan hasil sharing yang dilakukan dalam proses evaluasi tugas monitoring pasca pelatihan juga diketahui bahwa salah satu hal yang membuat para guru nyaman untuk berkomunikasi secara interpersonal hingga menjalin relasi interpersonal yang memuaskan pula dengan rekan kerjanya adalah faktor kesamaan latar belakang akademik, kesamaan tempat menimba ilmu dan kesamaan sifat. Selain itu jika dikaitkan dengan komitmen, maka pihakpihak yang merasakan adanya kesetaraan yang menyebabkan puasnya suatu komunikasi, juga akan merasakan rasa kebersamaan, eksklusifitas bersama dan keinginan untuk melanjutkan dan mempertahankan relasi yang telah dibina dan memuaskan. Hecht (Anderson \& Emmers-Sommer, 2006) kemudian menjelaskan lebih lanjut bahwa komunikasi interpersonal yang memuaskan dapat membantu individu untuk membangun hubungan yang memuaskan pula.

Sesi terakhir atau sesi ketiga akan menjelaskan tentang faktor-faktor efektifitas dan teknik meningkatkan komunikasi interpersonal secara lebih mendalam. Trainer akan menjelaskan dan membekali peserta tentang faktor-faktor dan teknik apa saja yang dapat meningkatkan efektifitas komunikasi interpersonal di tempat kerja. Saat seseorang sudah mengetahui faktor dan teknik apa saja yang dapat meningkatkan efektifitas komunikasi interpersonalnya, maka diperkirakan orang tersebut akan memiliki kompetensi komunikasi interpersonal yang 
baik dan kuat dalam kehidupannya. Individu dengan kemampuan komunikasi interpersonal yang kuat dapat mengatasi stres lebih baik, memiliki kepuasan relasi yang lebih baik dan memiliki banyak teman, mampu beradaptasi dengan perubahan hidup serta cenderung terhindar dari depresi dan kecemasan (Segrin \& Flora, 2000).

Ketiga sesi dalam pelatihan komunikasi interpersonal tersebut di atas diberikan kepada para guru di SD “A” dalam rangka meningkatkan kepuasan relasi para guru tersebut. Berdasarkan hasil pemberian sesi-sesi pelatihan tersebut di atas yang merupakan bagian dari penelitian ini, memang didapati bahwa terjadi peningkatan kepuasan relasi pada kelompok eksperimen setelah diberikannya perlakuan berupa pelatihan komunikasi interpersonal, dilihat dari hasil uji statistik yang dilakukan peneliti. Meskipun demikian generalisasi dari hasil penelitian ini akan lebih efektif jika diterapkan pada populasi penelitian yang memiliki ciri-ciri karakteristik sama dengan subjek pada penelitian ini. Berdasarkan hasil penelitian ini sendiri masih ada beberapa kesulitan yang dapat menjadi evaluasi dalam penelitian ini, antara lain peneliti belum sepenuhnya dapat mengontrol faktor-faktor yang mempengaruhi kepuasan relasi di luar variabel bebas di dalam penelitian ini seperti keadaan lingkungan di sekitar komunikan maupun komunikator (Cowen \& Cowen, 2000), keinginan subjek untuk menjalin hubungan (affiliation), faktor ketertarikan (attraction) dirasakan oleh individu tersebut, kemampuam membina hubungan, komitmen, kualitas komunikasi, kemampuan menyelesaikan konflik, afeksi, dan aturan dalam menjalani relasi. (Tedder \& Miller, 2011).

Selain itu pelaksanaan pelatihan yang hanya dilakukan dalam 5 jam mengingat keterbatasan waktu dan kesibukan subjek penelitian, walaupun peneliti memberikan tugas monitoring selama seminggu sebelum kegiatan sharing (evaluasi tugas monitoring pasca pelatihan) dilaksanakan. Selain itu dalam pelaksanaan pelatihan perlu adanya uji coba dan pembicaraan yang lebih intens lagi antara peneliti dan trainer agar ide dan pemahaman keduanya berada dalam jalur yang sama. Peneliti juga perlu melakukan survei mengenai jumlah subjek yang akan digunakan guna membantu peneliti dalam menentukan jenis dan desain penelitian.

\section{Kesimpulan}

Berdasarkan hasil penelitian dan pembahasan yang telah diuraikan sebelumnya dan menjawab perumusan masalah dalam penelitian ini, maka dapat ditarik kesimpulan bahwa pemberian pelatihan komunikasi interpersonal yang disusun oleh peneliti berdasarkan aspek-aspek komunikasi interpersonal seperti keterbukaan (openness), empati (empathy), dukungan (supportif), sikap positif (positiveness) dan kesetaraan (equality), terbukti berpengaruh pada peningkatan kepuasan relasi dengan rekan kerja pada guru. Hal ini disimpulkan berdasarkan uji hipotesis dengan menggunakan independent sample ttest terhadap gain score yang menunjukkan bahwa terdapat perbedaan tingkat kepuasan relasi antara kelompok eksperimen dengan 
kelompok kontrol dan juga dapat disimpulkan bahwa terjadi peningkatan kepuasan relasi khususnya pada kelompok eksperimen setelah mendapatkan pelatihan komunikasi interpersonal. Tingkat kepuasan relasi kelompok eksperimen yang mendapat pelatihan komunikasi interpersonal lebih tinggi dibandingkan tingkat kepuasan relasi kelompok kontrol yang tidak mendapat pelatihan komunikasi interpersonal.

\section{Saran}

Berdasarkan hasil penelitian, pembahasan dan kesimpulan di atas, maka peneliti merekomendasikan beberapa saran, sebagai berikut :

\section{Bagi Sekolah}

Guna meningkatkan kepuasan relasi yang berimplikasi pada peningkatan produktivitas kerja, penting bagi pihak sekolah untuk menyediakan sarana baik formal maupun informal bagi para gurunya untuk mengembangkan situasi komunikasi secara interpersonal, serta kegiatan-kegiatan yang dapat meningkatkan kepuasan relasi di antara sesama guru dan karyawan. Sebagai kontribusi lanjutan untuk membantu pihak sekolah dalam menjalankan saran di atas, maka peneliti merekomendasikan sekolah untuk mengadaptasi atau bahkan dapat mengembangkan program pelatihan maupun proses sharing yang peneliti rancang dalam penelitian ini, maupun dari sumber-sumber terpercaya lainnya. Selain itu peneliti juga merancang kegiatan follow up lanjutan yang dapat digunakan secara praktis, yang bertujuan untuk mempertahankan dan meningkatkan kemampuan komunikasi interpersonal yang dimiliki oleh guru di SD tempat penelitian ini dilaksanakan.

\section{Bagi Peneliti Selanjutnya}

Bagi peneliti yang ingin melanjutkan penelitian ini, beberapa hal yang disarankan peneliti adalah:

a. Memperdalam materi-materi di dalam modul pelatihan, baik dari segi kegiatan, pengukuran maupun hasil yang ingin dicapai, karena menurut peneliti pelatihan dalam penelitian ini masih belum menyentuh ranah perilaku, tetapi hanya sebatas reaksi dan pengetahuan mengenai komunikasi interpersonal.

b. Mengkaji dan menjaga secara lebih mendalam agar ancaman-ancaman penelitian yang dapat mempengaruhi validitas internal tidak turut mempengaruhi pengaruh variabel bebas terhadap variabel terikat.

\section{DAFTAR PUSTAKA}

Anderson, T. L., \& Emmers-Sommer, T. M. (2006). Predictor of relationship satisfaction in online romantic relationship. Communication Studies, 57, 153-172. doi:10.1080/10510970600666834

Anderson, C. M., \& Martin, M. M. (2009). Why employees speak to coworkers and bosses: Motives, gender, and organizational satisfaction. Journal of Business Communication, 32, 249-265. doi:10.1177/002194369503200303 
Cutlip, S. M., \& Allen, H. C. (2000). Effective public relations. Wisconsin: Prentice Hall.

DeVito, J. (2006). Human communication. Boston: Pearson Education.

Hobfoll, S. E. (1986). Stress, social support and women: The series in clinical and community psychology. New York: Herper \& Row.

Magnus, U. (2009) Success of an organization depend on the manager's communication skills. Diunduh dari http//:www.AssociatedContent.com tanggal 21 September 2014.

Muhammad, A. (2005). Komunikasi organisasi. Jakarta: Bumi Aksara.

Murtiningrum, A. (2005). Analisis pengaruh konflik pekerjaan-keluarga terhadap stres kerja dengan dukungan sosial sebagai variabel moderasi. (Tesis tidak dipublikasikan). Program Studi MM Pascasarjana Universitas Diponegoro, Semarang.

Negri, B. D., Brown, L. D., Hernández, O., Rosenbaum, J., \& Roter, D. (1993). Quality assurance methodology refinement series. Improving interpersonal communication between health care providers and clients. Wisconsin: Quality Assurance Project.

Orebiyi, A. O., \& Orebiyi, T. P. (2011). The influence of interpersonal communication on secondary school teachers' job satisfaction and commitment in Kogi State, Nigeria. Journal of Communication and Culture: International Perspective, 2(1).

Panggabean, M. S. (2002). Manajemen sumber daya manusia. Jakarta: Ghalia Indonesia.

Qolbi, A. I. (2013). Hubungan antara komunikasi interpersonal dengan iklim organisasi di SDN 034 Samarinda. eJournal Ilmu Komunikasi, 1(1), 22-38.

InSight, Tahun XIII/Nomor 1/Februari 2016
Robbins, S. P. (1996). Organizational behavior. Concept, controversies, application. New Jersey: Prentice-Hall.

Roethlisberger, F. J., \& Dickson, W. J. (1939). Management and the worker: An account of a research program conducted by the Western electric company, Hawthrone Works, Chicago. Cambridge, MA: Harvard University Press.

Rosenholtz, S. J. (1989). Teachers' workplace: The social organization of schools. New York: Longman.

Rubent, B. D. (1998). Communication and human behavior. Boston: Allyn and Bacon

Rubin, H., \& Rubin, I. (1995). Qualitative interviewing : The art of hearing data. Thousand Oaks, CA: Sage.

Segrin, G., \& Flora, J. (2000). Poor social skills are a vulnerability factor in the development of psychological problems. Human Communication Research, 26(3).

Shadish, W. R., Cook, T. D., \& Campbell D. T. (2002). Experimental and quasiexperimental designs for generalized causal inference. Boston: Houghton Mifflin Company.

Simon, L. S., Judge, T. A., \& HalvorsenGanepola, M. D. K. (2010). In good company? A multi-study, multi-level investigation of the effects of coworker relationships on employee well-being. Journal of Vocational Behavior, 76, 534-546.

Sugiyono. (2010). Metode Penelitian bisnis pendekatan kuantitatif, kualitatif, dan $R$ \& D. Bandung: CV. Alfabeta.

Susilowati, M. (2012). Peningkatan kompetensi komunikasi interpersonal dan kinerja pre ops pilot selama masa percobaan di PT. X dengan memberikan pelatihan komunikasi interpersonal yang efektif. (Tesis tidak dipublikasikan). Program Studi Psikologi Profesi Universitas Indonesia, Depok.

Training Model Primary Providers. (2006). Training curriculum in interpersonal 
communication, referral and follow-up

process, and selected practices in infection prevention and control. Ministry of Health in Iraq.

West, R., \& Turner, L. H. (2009). Understanding interpersonal communication: Making choices in changing times. Boston: Lyn Uhl. 